\title{
SEKRETARIS DESA DALAM PEMERINTAHAN DESA
}

\author{
Munif Rochmawanto \\ Dosen Fakultas Hukum Universitas Islam Lamongan
}

\begin{abstract}
ABSTRAK
Setiap aturan hukum yang dibuat selalu mempunyai tujuan, yaitu kepastian hukum, keadilan dan manfaat. Bagaimanakah kedudukan Sekretaris Desa dalam pemerintahan desa berdasarkan Peraturan Pemerintah Nomor 72 Tahun 2005 tentang Desa? Bagaimanakah persyaratan dan tata cara pengangkatan Sekretaris Desa menjadi Pegawai Negeri Sipil (PNS)?. Untuk mengetahui kedudukan Sekretaris Desa dalam pemerintahan desa berdasarkan Peraturan Pemerintah Nomor 72 Tahun 2005 tentang Desa.Untuk mengetahui tentang persyaratan dan tata cara pengangkatan Sekretaris Desa tersebut untuk menjadi PNS. Tipe penelitian hukum yang dilakukan adalah yuridis normatif. Metode penelitian hukum normatif adalah suatu prosedur penelitian ilmiah untuk menemukan kebenaran berdasarkan logika keilmuan hukum dari sisi normatifnya. Pendekatan yang digunakan adalah pendekatan perundang-undangan, tentang pengkajian peraturan perundang-undangan yang berhubungan dengan pokok permasalahan. Sekretaris Desa yang tidak diangkat menjadi PNS mengikuti Peraturan Pemerintah Nomor 72 Tahun 2005 tentang Desa, usia maksimum enam puluh tahun. Sekretaris Desa yang diangkat menjadi PNS mengikuti Peraturan Pemerintah Nomor 65 Tahun 2008 tentang Pemberhentian PNS usia pensiun lima puluh enam tahun. Untuk jabatan Sekretaris Desa yang kosong diisi oleh masyarakat yang bukan dari PNS akan tetapi diambil dari masyarakat setempat. Pemerintah daerah Kabupaten/Kota membuat aturan yang lebih jelas dalam hal Sekretaris Desa, khususnya tentang penarikan tanah bengkok Sekretaris Desa yang diangkat menjadi PNS.
\end{abstract}

Kata kunci : Sekretaris desa, Pemerintahan desa.

\section{PENDAHULUAN}

\subsection{Latar Belakang}

Dengan perkembangan zaman pergaulan manusia semakin luas, begitu juga dengan kebutuhan manusia. Bertambahnya kebutuhan manusia semakin besar, maka keinginan untuk melindungi dan memelihara keselamatan hidupnya pun semakin tinggi pula. Kehidupan sosial yang dibangun diatas berbagai kepentingan dan kebutuhan, melahirkan kaidah yang mengatur simpang siur kepentingan dan kebutuhan antar manusia. ${ }^{[1]}$ Oleh karena itu salah satu manusia dalam menjalani hidupnya untuk mewujudkan keinginannya dengan cara berorganisasi. Dengan organisasi manusia tidak lepas dari politik. Menurut Aristoteles, manusia adalah Zoon
Politicon atau makhluk yang hidup bermasyarakat. Kehidupan bermasyarakat setiap harinya menghadapi realitas absolut yang berkaitan dengan strata sosial, status sosial, harga diri, kasta-kasta dan kelaskelas sosial lainnya yang merupakan indikator bahwa garis nasib dan takdir manusia berbeda-beda. ${ }^{[2]}$ Akhirnya kehidupan manusia sampai seperti sekarang ini yang dimana masyarakatnya hidup bernegara, berorganisasi dan tidak lepas dari peraturan yang dibuat oleh negara tersebut. Hukum atau peraturan adalah ketentuan-ketentuan yang menjadi peraturan hidup suatu masyarakat yang bersifat mengendalikan, mencegah, mengikat, dan memaksa. ${ }^{[3]}$ Menurut Soerjono Soekanto, hukum atau peraturan yang tertulis dapat berbentuk undang- 
undang, peraturan pemerintah, keputusan pengadilan, intruksi presiden, dan sebagainya, sedangkan peraturan yang tidak tertulis merupakan perbuatan masyarakat yang bersifat tradisional normatif, seperti hukum adat. ${ }^{[4]}$ Hukum adat sering ditemukan di desa-desa. Desa adalah kesatuan masyarakat hukum yang memiliki batas-batas wilayah yang berwenang untuk mengatur dan mengurus kepentingan masyarakat setempat, berdasarkan asal-usul dan adat-istiadat setempat yang diakui dan dihormati dalam sistim pemerintahan Negara Kesatuan Republik Indonesia, yang berada di daerah kabupaten. Desa merupakan masuk pemerintahan yang terkecil dari suatu negara. Setiap desa mempunyai aturan yang disebut dengan Peraturan Desa (Perdes). Peraturan desa dibuat oleh Kepala Desa beserta Badan Permusyawaratan Desa (BPD). Semua masyarakat yang ada di desa tersebut wajib mentaati peraturan desa itu, begitu juga dengan pemerintah desanya. Setiap desa peraturan desanya tidak selalu sama, peraturan tersebut dibuat dalam rangka untuk penyelenggaraan pemerintahan desa. Pemerintahan desa adalah penyelenggaraan urusan pemerintahan oleh pemerintah desa dan Badan Permusyawaratan Desa dalam mengatur dan mengurus kepentingan masyarakat setempat berdasarkan asal-usul dan adatistiadat setempat yang diakui dan dihormati dalam sistim pemerintahan Negara Kesatuan Republik Indonesia. Peraturan desa tidak boleh bertentangan dengan peraturan perundang-undangan yang lebih tinggi. Oleh karena itu Peraturan Desa kebanyakan merujuk pada peraturan yang lebih tinggi derajatnya, begitu juga dengan peraturan tentang sekretaris desa. Sekretaris Desa adalah perangkat desa yang bertugas membantu Kepala Desa dalam bidang tertib administrasi pemerintahan dan pembangunan serta pelayanan dan pemberdayaan masyarakat. Sekretaris desa termasuk perangkat desa yang tertuang di dalam Peraturan Pemerintah Nomor 72 Tahun 2005 tentang Desa, Pasal 12 ayat (2) yang berbunyi :
"Perangkat Desa sebagaimana dimaksud pada ayat (1) terdiri dari Sekretaris Desa dan Perangkat Desa lainnya".

Jumlah perangkat desa di setiap desa disesuaikan dengan kebutuhan desa setempat dan kondisi sosial budaya masyarakat setempat. Usia pensiun perangkat desa adalah paling tinggi 60 (enam puluh) tahun, yang terdapat di Peraturan Pemerintah Nomor 72 Tahun 2005 tentang Desa, Pasal 26 ayat (3) yang berbunyi :

"Usia Perangkat Desa sebagaimana dimaksud pada ayat (1) paling rendah 20 (dua puluh) tahun dan paling tinggi 60 (enam puluh) tahun".

dan Peraturan Bupati Nomor 23 Tahun 2007 tentang Tata Cara Pencalonan, Pengangkatan dan Pelantikan Perangkat Desa lainnya Bab V Pasal 23 ayat (1) berbunyi :

"Masa Jabatan Perangkat Desa Lainnya dibatasi usia sampai dengan 60 (enam puluh) tahun".

Dengan berjalannya waktu perkembangan zaman mempengaruhi peranan peraturan perundang-undangan semakin meningkat. Akan tetapi patut disayangkan dengan peraturan yang baru tersebut kadang kala diikuti dengan permasalahan yang baru juga. Salah satu penyebab masalah tersebut adalah tentang Sekretaris Desa. Dalam pembuatan suatu peraturan tidak boleh mengabaikan hierarki peraturan perundang-undangan.

Menurut Hans Kelsen : Norma-norma hukum itu berjenjang-jenjang dan berlapis-lapis dalam suatu hierarki susunan. ${ }^{[5]}$ Suatu norma yang lebih rendah berlaku, bersumber, dan berdasar pada norma lain yang lebih tinggi lagi, demikian seterusnya norma itu berlaku. ${ }^{[6]}$ Norma adalah suatu ukuran yang harus dipatuhi oleh seseorang dalam hubungannya dengan sesamanya ataupun dengan lingkungannya. ${ }^{[7]}$ Peraturan perundang-undangan yang lebih rendah derajatnya tidak dapat mengubah atau mengesampingkan ketentuan-ketentuan perundang-undangan yang lebih tinggi, tetapi yang sebaliknya dapat. ${ }^{[8]}$ Berdasarkan Undang-Undang Nomor 12 Tahun 2011 tentang hierarkhi peraturan 
perundang-undangan, susunan peraturan perundang-undangan di Indonesia adalah sebagai berikut :

1. Undang-Undang Dasar Negara Republik Indonesia 1945.

2. Ketetapan Majelis Permusyawaratan Rakyat.

3. Undang-Undang / Peraturan

Pemerintah Pengganti Undang-Undang.

4. Peraturan Pemerintah

5. Peraturan Presiden.

6. Peraturan Daerah Propinsi dan

7. Peraturan Daerah Kabupaten / Kota.

Walaupun sudah diklasifikasikan sesuai status sekretaris desa masingmasing, tidak ada salahnya kalau peraturan tentang sekretaris desa itu lebih diperjelas dan disosialisasikan terlebih dahulu untuk mengantisipasi sesuatu yang tidak diinginkan itu terjadi dikemudian hari. Dalam hal ini peranan Kepala Desa sangat dibutuhkan untuk bertindak tegas bila ada sekretaris desanya melakukan pelanggaran terutama mengenai usia pensiun. Kekosongan Sekretaris Desa di dalam Pemerintah Desa, sangat disayangkan. Di sisi lain pemerintah mengangkat Sekretaris Desa menjadi PNS, karena dilihat peranan Sekretaris Desa yang begitu penting dan di sisi lain beberapa Pemerintah Desa tidak mempunyai Sekretaris Desa. Kekosongan Sekretaris Desa akan diisi dari orang PNS dan akan ditempatkan di tempat tersebut yang jabatan Sekretaris Desanya kosong. Tetapi untuk mencari seseorang pengganti Sekretaris Desa yang berhenti tersebut sangatlah sulit, mengingat Pemerintahan Desa adalah pemerintahan yang terkecil dan apabila ada yang mengisi kekosongan Sekretaris Desa maka orang tersebut bisa berasal dari Pemerintahan Desa, Kelurahan atau dari Kecamatan. Dan itu artinya bagi orang tersebut benar-benar mengutamakan pengabdian yang luar biasa. Oleh karena itu alangkah baiknya Sekretaris Desa itu diambil dari masyarakat biasa yang tidak PNS dan dari daerah setempat agar kekosongan jabatan Sekretaris Desa tersebut tidak berlamalama.

\subsection{Perumusan Masalah}

Berdasarkan latar belakang tersebut diatas maka penulis mengetengahkan dua permasalahan yaitu :
1. Bagaimanakah kedudukan sekretaris desa dalam pemerintahan desa berdasarkan Peraturan Pemerintah Nomor 72 Tahun 2005 tentang Desa?

2. Bagaimanakah persyaratan dan tata cara pengangkatan sekretaris desa menjadi pegawai negeri sipil ?

\subsection{Tujuan Penelitian}

Tujuan penelitian ini sebagai barometer untuk menguji tingkat pemahaman penulis atas proses transfer ilmu hukum selama di Fakultas Hukum Universitas Islam Lamongan. Selain itu, untuk diajukan guna memenuhi persyaratan penulisan skripsi dan memperoleh gelar Sarjana Hukum di Fakultas Hukum Universitas Islam Lamongan.

Penulisan ini bertujuan untuk ditujukan pada sekretaris desa, agar mengikuti peraturan yang sudah ditentukan untuk dijalankan semestinya menurut statusnya masing-masing dan tidak diperbolehkan mengikuti dua aturan sekaligus dalam menjalankan tugasnya. Berdasarkan Pasal 3 ayat (2) Peraturan Pemerintah Nomor 32 Tahun 1979 tentang Pemberhentian Pegawai Negeri Sipil (PNS), yang diubah menjadi Peraturan Pemerintah Nomor 65 Tahun 2008 bagi yang diangkat sebagai Pegawai Negeri Sipil (PNS) dan yang tidak diangkat menjadi Pegawai Negeri Sipil (PNS) mengikuti Peraturan Pemerintah Nomor 72 Tahun 2005 tentang Desa. Adapun beberapa tujuan yang didapat dalam penulisan ini adalah :

1. Untuk mengetahui kedudukan Sekretaris Desa dalam pemerintahan desa berdasarkan Peraturan Pemerintah Nomor 72 Tahun 2005 tentang Desa.

2. Untuk mengetahui secara mendalam tentang persyaratan dan tata cara pengangkatan Sekretaris Desa tersebut untuk menjadi Pegawai Negeri Sipil (PNS).

\section{Metode Penelitian}

Tipe penelitian hukum yang dilakukan adalah yuridis normatif (hukum normatif). Metode penelitian hukum normatif adalah suatu prosedur penelitian ilmiah untuk menemukan kebenaran berdasarkan logika keilmuan hukum dari sisi normatifnya. ${ }^{[9]}$ Maka dari itu penelitian 
hukum ini untuk mengkaji penelitian tentang norma-norma dalam hukum yuridis normatif, yang berkaitan dengan pemerintahan desa khususnya tentang sekretaris desa yang diangkat menjadi Pegawai Negeri Sipil (PNS) maupun yang tidak diangkat menjadi Pegawai Negeri Sipil (PNS).

Karena tipe penelitian yang digunakan adalah tipe penelitian yuridis normatif, maka pendekatan yang digunakan adalah pendekatan perundang-undangan (statute approach). Pendekatan tersebut melakukan pengkajian peraturan perundang-undangan yang berhubungan dengan pokok permasalahan.

Disamping itu juga menggunakan pendekatan konseptual. Pendekatan konseptual ini beranjak dari pandanganpandangan dan doktrin-doktrin yang berkembang di dalam ilmu hukum. Dengan mempelajari konsep tersebut melalui pandangan-pandangan dan doktrin-doktrin, maka peneliti akan menemukan sesuatu ideide yang cemerlang yang sesuai dengan isuisu yang dihadapi.

\section{Hasil dan Pembahasan}

Dari hasil penelitian ini dapat disimpulkan bahwa :

1. Sekretaris Desa yang tidak diangkat menjadi PNS mengikuti Peraturan Pemerintah Nomor 72 Tahun 2005 tentang Desa dengan usia maksimal 60 (enam puluh) tahun atau Sekretaris Desa diberhentikan dari jabatannya secara hormat dengan diberikan tunjangan kompensasi sesuai dengan masa kerja. Sementara tentang kekosongan Sekretaris Desa yang di desa-desa, penulis berharap diambilkan dari masyarakat setempat dari desa tersebut kemudian persyaratan dan tata cara pengangkatan Sekretaris Desa dilakukan sama seperti Perangkat Desa lainnya.

2. Sekretaris Desa yang diangkat menjadi PNS mengikuti Peraturan Pemerintah Nomor 65 Tahun 2008 tentang Perubahan Kedua Atas Peraturan Pemerintah Nomor 32 Tahun 1979 tentang Pemberhentian Pegawai Negeri Sipil dengan usia pensiun 56 (lima puluh enam) tahun. Dan sejak SK pengangkatan Sekretaris Desa menjadi PNS, tanah bengkok harus diserahkan ke desa. Tentang kekosongan jabatan Sekretaris Desa yang diambil dari PNS, sebaiknya diambil dari masyarakat setempat yang bukan PNS. Untuk lebih jelas aturan tersebut agar Pemerintahan Daerah membuat peraturan tentang Sekretaris Desa, terutama tentang tanah bengkok dan kekosongan jabatan Sekretaris Desa.

Desa adalah kesatuan masyarakat hukum yang memiliki batas-batas wilayah yang berwenang untuk mengatur dan mengurus kepentingan masyarakat setempat, berdasarkan asal-usul dan adatistiadat setempat yang diakui dan dihormati dalam sistem pemerintahan Negara Kesatuan Republik Indonesia, dan yang berada di daerah kabupaten. Berdasarkan Peraturan Pemerintah Nomor 72 Tahun 2005 tentang Desa. Desa dibentuk atas prakarsa masyarakat dengan memperhatikan asal-usul desa dan kondisi sosial budaya masyarakat setempat.

Syarat pembentukan desa adalah :

1. Jumlah penduduk

2. Luas wilayah

3. Bagian wilayah kerja

4. Perangkat dan

5. Sarana dan prasarana pemerintahan

Pemerintahan Desa adalah penyelenggaraan urusan pemerintah desa dan badan permusyawaratan desa dalam mengatur dan mengurus kepentingan masyarakat setempat berdasarkan asal-usul dan adat-istiadat setempat yang diakui dan dihormati dalam sistem pemerintahan Negara Kesatuan Republik Indonesia.

Setiap desa pasti mempunyai Peraturan Desa (Perdes), karena Peraturan desalah yang mengatur segala sesuatu prilaku masyarakat desa tersebut, agar masyarakat hidup tertib, aman dan damai. Masyarakat desa selain mematuhi peraturan desa juga mematuhi aturan yang dibuat oleh negara, seperti :

1. UUD 1945

2. Ketetapan MPR

3. Undang-Undang / Peraturan Pemerintah Pengganti Undang-Undang

4. Peraturan Pemerintah

5. Peraturan Presiden

6. Peraturan Daerah Propinsi

7. Peraturan Daerah Kabupaten/Kota 
Setiap aturan hukum yang dibuat selalu mempunyai tujuan yaitu :

1. Kepastian hukum

2. Keadilan dan

3. Manfaat

Tiga asas tersebut diatas merupakan satu kesatuan yang tidak bisa dipisahkan satu dengan yang lainnya. Apabila dari tiga asas tersebut salah satu dari tiga asas itu tidak dipergunakan, maka tujuan hukumpun tidak sempurna lagi. Karena apa yang diharapkan oleh masyarakat tidak pernah tercapai. Dalam pembuatan suatu peraturan tidak boleh mengabaikan hierarki peraturan perundang-undangan. Peraturan perundangundangan yang lebih rendah derajatnya tidak dapat mengubah atau mengesampingkan ketentuan-ketentuan perundang-undangan yang lebih tinggi, tetapi yang sebaliknya dapat. Sebuah peraturan perundang-undangan yang baik paling sedikit harus memiliki tiga landasan, yaitu landasan filosofis (filosofische grondslag), landasan sosiologis (sociologische grondslag), dan landasan yuridis (rechtsgrond).${ }^{[10]}$

Desa merupakan masuk pemerintahan yang terkecil dari suatu negara. Desa bisa dikatakan sebagai sumber nilai leluhur yang memiliki karakteristik seperti kegotongroyongan, musyawarah, mufakat dan kekeluargaan, yang dimana tidak dimiliki oleh masyarakat perkotaan. Selain itu juga masyarakat desa tidak lepas dari hukum adat dalam menjalani hidupnya. Adat itu ada karena prilaku dari kebiasaan pribadi seseorang kemudian ditiru oleh orang lain lambat laun menjadi kebiasaan masyarakat tersebut dan akhirnya menjadi hukum adat di daerah itu. Hukum adat adalah adat yang diterima dan harus dilaksanakan dalam masyarakat bersangkutan. ${ }^{[11]}$ Pada umumnya kehidupan masyarakat di desa mempunyai corak yang tradisional, keagamaan, kebersamaan, konkrit dan visual, terbuka dan sederhana, dapat berubah dan menyesuaikan, musyawarah dan mufakat. ${ }^{[12]}$

Sekretaris Desa merupakan benteng bagi pemerintah desa dan secara tidak langsung sekaligus sebagai wakil dari Kepala Desa. Terbukti apabila Kepala Desa berhalangan dalam menjalankan tugasnya, maka Sekretaris Desa yang akan menggantikannya. Mengingat peranan Sekretaris Desa yang begitu penting, maka Sekretaris Desa yang memenuhi persyaratan diangkat menjadi Pegawai Negeri Sipil (PNS). Pegawai Negeri adalah setiap Warga Negara Republik Indonesia yang telah memenuhi syarat yang ditentukan, diangkat oleh pejabat yang berwenang dan diserahi tugas dalam jabatan negeri atau disertai tugas negara lainnya dan digaji berdasarkan perundangundangan yang berlaku. Kedudukan Sekretaris Desa menjadi Pegawai Negeri Sipil (PNS) sampai saat ini belum terlihat secara jelas pengerjaan administrasi yang baik dan begitu juga pelayanan terhadap masyarakat secara profesional. Sekretaris Desa seperti itu karena persyaratan menjadi PNS belum dijalankan secara benar-benar khususnya dalam kemampuan di bidang administrasi perkantoran, tentunya harus bisa komputer. Terbukti banyak Sekretaris Desa yang tidak bisa menjalankan komputer. Sementara tugas Sekretaris Desa adalah mencatat segala sesuatu kegiatan yang ada di dalam pemerintahan desa terutama dalam hal urusan administrasi keuangan desa dan buku administrasi desa. Pengangkatan Sekretaris Desa menjadi PNS tidak diimbangi dengan kinerja yang lebih baik dan profesional, misalnya tentang pelayanan terhadap masyarakat dan tertib administrasi. Artinya Sekretaris Desa diangkat menjadi PNS oleh pemerintah itu baik bagi pribadi Sekretaris Desa itu sendiri, tetapi tidak baik bagi pemerintah desa. Karena bila ditinjau dari kinerjanya antara Sekretaris Desa yang menjadi PNS dengan sebelumnya tidak ada perubahan yang terlihat.

Sekretaris Desa yang diangkat menjadi PNS dan sudah pensiun dengan usia 56 (lima puluh enam) tahun, tidak dibenarkan jika Sekretaris Desa tersebut masih tetap bertugas di balai desa dan masih tetap menguasai tanah bengkok tersebut. Tanah bengkok harus diserahkan kepada pemerintah desa, sejak SK pengangkatan menjadi PNS itu sudah diterimanya. Apabila Sekretaris Desa sudah pensiun dari PNSnya kemudian masih bertugas sambil menunggu usia 60 (enam puluh) tahun dan masih menggarap tanah bengkok, maka Sekretaris Desa tersebut 
akan mengembalikan uang gaji dari PNSnya selama Sekretaris Desa menjabat, karena Sekretaris Desa dianggap mengikuti aturan Peraturan Pemerintah Nomor 72 Tahun 2005 tentang Desa dan tidak mengikuti Peraturan Pemerintah Nomor 65 Tahun 2008 tentang Perubahan Kedua Atas Peraturan Pemerintah Nomor 32 Tahun 1979 tentang Pemberhentian Pegawai Negeri Sipil.

Dalam perkembangan zaman, sesuai dengan ketentuan Undang-Undang Nomor 8 Tahun 2005 tentang Perubahan atas Undang-Undang Nomor 32 Tahun 2004 tentang Pemerintahan Daerah. Sekretaris Desa yang memenuhi persyaratan sesuai dengan ketentuan Peraturan Perundangundangan akan diangkat secara bertahap menjadi Pegawai Negeri Sipil (PNS). Persyaratan tersebut berdasarkan Peraturan Pemerintah Nomor 45 Tahun 2007 tentang persyaratan dan tata cara pengangkatan Sekretaris Desa menjadi Pegawai Negeri Sipil (PNS) sebagai berikut :

1. Bertaqwa kepada Tuhan Yang Maha Esa.

2. Setia kepada Pancasila sebagai Dasar Negara, Undang-Undang Dasar Negara Republik Indonesia Tahun 1945 dan kepada Negara Kesatuan Republik Indonesia serta Pemerintah.

3. Tidak sedang menjalani hukuman karena melakukan tindak pidana berdasarkan putusan pengadilan yang mempunyai kekuatan hukum tetap.

4. Sehat jasmani dan rohani.

5. Memiliki ijazah paling rendah Sekolah Dasar atau yang sederajat dan

6. Berusia paling tinggi 51 (lima puluh satu) tahun berdasarkan pada 15 Oktober 2006.

Berdasarkan Peraturan Pemerintah Nomor 45 Tahun 2007 tentang persyaratan dan tata cara pengangkatan Sekretaris Desa menjadi PNS dalam hal pangkat/golongan adalah Sekretaris Desa yang memenuhi persyaratan diangkat sebagai PNS dalam pangkat Pengatur Muda golongan ruang II/a. Sekretaris Desa yang memiliki ijazah lebih tinggi dari Surat Tanda Tamat Belajar (STTB) Sekolah Lanjutan Tingkat Atas (SLTA) diangkat sebagai PNS dalam pangkat/golongan ruang sesuai dengan ijazah SLTA. Sekretaris Desa yang memiliki ijazah lebih rendah dari STTB, SLTA diangkat sebagai PNS dalam pangkat/golongan ruang sesuai dengan ijazah yang dimiliki. Pegawai Negeri Sipil, selanjutnya disingkat PNS adalah mereka yang telah memenuhi syarat-syarat yang ditentukan dalam Peraturan Perundangundangan, diangkat oleh pejabat yang berwenang dan diserahi tugas-tugas dalam sesuatu jabatan negeri atau diserahi tugas negara lainnya yang ditetapkan berdasarkan sesuatu peraturan perundang-undangan dan digaji menurut peraturan perundangundangan.

Tata Cara Pengangkatan Sekretaris Desa menjadi Pegawai Negeri Sipil (PNS) adalah :

1. Bupati/Walikota menyusun data Sekretaris Desa di wilayahnya.

2. Bupati/Walikota mengumpulkan berkas pengangkatan Sekretaris Desa.

3. Data Sekretaris Desa dan berkas pengangkatan disampaikan oleh Bupati/Walikota kepada Menteri Dalam Negeri melalui Gubernur.

4. Menteri Dalam Negeri melakukan verifikasi dan validasi data dan berkas.

5. Menteri Dalam Negeri mengajukan usulan formasi Sekretaris Desa untuk Kabupaten/Kota kepada Menteri Negara Pendayagunaan Aparatur Negara dan tembusannya disampaikan kepada Kepala Badan Kepegawaian Negara.

6. Pengangkatan Sekretaris Desa menjadi Pegawai Negeri Sipil (PNS) dilakukan secara bertahap sesuai formasi yang ditetapkan oleh Menteri Negara Pendayagunaan Aparatur Negara.

7. Pengangkatan Sekretaris Desa menjadi Pegawai Negeri Sipil (PNS) dilakukan secara bertahap mulai formasi tahun 2007 dan selesai paling lambat tahun 2009.

8. Formasi pengangkatan Sekretaris Desa menjadi Pegawai Negeri Sipil (PNS), dialokasikan pada tiap Kecamatan.

9. Pengangkatan Sekretaris Desa secara bertahap dilakukan dengan memprioritaskan usia paling tinggi.

10. Menteri Dalam Negeri mengusulkan persetujuan pengangkatan Sekretaris Desa menjadi Pegawai Negeri Sipil 
(PNS) kepada Kepala Badan Kepegawaian Negara.

11. Kepala Badan Kepegawaian Negara memberikan persetujuan dan penetapan Nomor Identitas PNS (NIP) pengangkatan Sekretaris Desa menjadi Pegawai Negeri Sipil (PNS) dan diteruskan kepada Menteri Dalam Negeri.

12. Persetujuan pengangkatan Sekretaris Desa diteruskan oleh Menteri Dalam Negeri kepada Bupati/Walikota melalui Gubernur.

13. Berdasarkan Persetujuan Kepala Badan Kepegawaian Negara dan Surat Menteri Dalam Negeri, Bupati/Walikota menetapkan keputusan pengangkatan Sekretaris Desa menjadi Pegawai Negeri Sipil (PNS).

Dalam hal pengangkatan Sekretaris Desa yang tidak diangkat menjadi PNS ada dua kebijaksanaan dari Pemerintah yaitu :

1. Sekretaris Desa tetap bertugas di balai desa sampai dengan batas usia 60 (enam puluh) tahun, seperti sebelumnya Peraturan Pemerintah Nomor 72 Tahun 2005 tentang Desa.

2. Sekretaris Desa yang tidak diangkat menjadi PNS diberhentikan dari jabatannya oleh Bupati/Walikota dengan diberikan tunjangan kompensasi yang dihitung berdasarkan masa kerja selama yang bersangkutan menjadi Sekretaris Desa.

Penghitungan tunjangan kompensasi adalah sebagai berikut:

a. Masa kerja 1 (satu) sampai dengan 5 (lima) tahun ditetapkan sebesar Rp. 5.000.000,- (lima juta rupiah).

b. Masa kerja lebih dari 5 (lima) tahun dihitung sebesar Rp. $1.000 .000,-$ (satu juta rupiah) pertahun, dengan ketentuan secara kumulatif paling tinggi Rp. 20.000.000,- (dua puluh juta rupiah).

Penetapan besaran tunjangan kompensasi bagi setiap Sekretaris Desa ditetapkan dengan Keputusan Bupati/Walikota Dana Tunjangan Kompensassi dibebankan pada Anggaran Pendapatan dan Belanja Daerah (APBD) Kabupaten/Kota.

\section{Penutup}

\subsection{Kesimpulan}

Berdasarkan uraian yang telah dipaparkan pokok permasalahan maupun pembahasan pada bab terdahulu, penulis dapat menyimpulkan beberapa hal :

1. Sekretaris Desa yang tidak diangkat menjadi PNS mengikuti aturan Peraturan Pemerintah Nomor 72 Tahun 2005 tentang Desa dengan usia maksimal 60 (enam puluh) tahun atau Sekretaris Desa diberhentikan dari jabatannya secara hormat dengan diberikan tunjangan kompensasi sesuai dengan masa kerja. Sementara kekosongan jabatan Sekretaris Desa yang di Pemerintahan Desa akan diisi dari seorang PNS, namun belum ada aturan yang mengatur secara jelas tentang hal itu. Sehingga banyak Pemerintah Desa yang tidak mempunyai Sekretaris Desa.

2. Sekretaris Desa yang diangkat menjadi PNS, dengan mengacu pada Peraturan Pemerintah Nomor 65 Tahun 2008 tentang Perubahan Kedua Atas Peraturan Pemerintah Nomor 32 Tahun 1979 tentang Pemberhentian PNS, dengan usia pensiun 56 (lima puluh enam) tahun. Sementara syarat dan tata cara pengangkatan Sekretaris Desa menjadi PNS mengikuti aturan Peraturan Pemerintah Nomor 45 Tahun 2007 tentang persyaratan dan tata cara pengangkatan Sekretaris Desa menjadi PNS. Sekretaris Desa yang PNS jika sudah pensiun dengan usia 56 (lima puluh enam) tahun tidak diperbolehkan mengikuti aturan Peraturan Pemerintah Nomor 72 Tahun 2005 tentang Desa dan memanfaatkan tanah bengkok untuk digarapnya. Apabila itu terjadi maka uang gaji dari PNSnya akan diminta untuk mengembalikan kepada pemerintah karena itu merupakan pelanggaran.

\subsection{Saran}

Dalam menunjang perkembangan hukum nasional hendaknya diciptakan atau dibuat sesuatu peraturan yang mudah dijalankan agar persoalan-persoalan tersebut diatas khususnya tentang Sekretaris Desa bisa terselesaikan secara 
maksimal, adil dan bijaksana. Oleh karena itu alangkah baiknya jabatan Sekretaris Desa yang kosong diisi oleh masyarakat yang bukan dari PNS akan tetapi diambil dari masyarakat setempat dengan syarat dan prosedur seperti pencalonan Perangkat Desa lainnya.

Pembinaan dan pengawasan yang sudah dilakukan oleh pejabat yang berwenang kurang maksimal dalam hal pembinaan dan pengawasan terhadap Pemerintah Desa. Penulis berharap, agar pemerintah daerah Kabupaten/Kota membuat aturan yang lebih jelas dalam hal Sekretaris Desa, khususnya tentang penarikan tanah bengkok Sekretaris Desa yang diangkat menjadi PNS. Karena selama ini permasalahan tersebut di lapangan belum juga terselesaikan secara bijaksana. Penarikan tanah bengkok Sekretaris Desa, bisa ditarik dan diserahkan ke desa apabila ada payung hukumnya yang kuat dan jelas.

\section{Catatan Kaki :}

[1] Beni Ahmad Saebani. Sosiologi

Hukum. CV Pustaka Setia. Bandung. 2007. h. 146

$\left[{ }^{2}\right]$ Ibid h. 11

$\left[{ }^{3}\right]$ Ibid h. 12

$\left.{ }^{4}\right]$ Ibid h. 16

$\left[{ }^{5}\right]$ Budiman N.P.D Sinaga. Ilmu

Pengetahuan Perundang-Undangan. UII Press. Yogyakarta. 2004. h. 18

$\left[{ }^{6}\right]$ Ibid

[7] Ibid h. 7

$\left[{ }^{8}\right]$ Ibid h. 19

[9] Jhonny Ibrahim. Teori dan Metode

Hukum Normatif. Banyumedia Publishing.

Malang. 2006. h. 57

[ $\left.{ }^{1} 0\right]$ Budiman N.P.D Sinaga. Op.cit. h.32

$\left[1^{1}\right]$ Hilman Hadikusuma. Pengantar Ilmu

Hukum Adat Indonesia. Mandar Maju.

Bandung. 1992. h.1

[2] Ibid h.33

\section{Daftar Pustaka}

\section{LITERATUR :}

Beni Ahmad Saebani, Sosiologi Hukum, CV

Pustaka Setia, Bandung, 2007.
Budiman N.P.D Sinaga, Ilmu Pengetahuan Perundang-Undangan, UII Press, Yogyakarta, 2004.

Hilman Hadikusuma, Pengantar Ilmu Hukum Adat Indonesia, Mandar Maju, Bandung, 1992.

Jhonny Ibrahim, Teori \& Metode Penelitian hukum Normatif, Banyumedia, Malang, 2006.

Peter Mahmud Marzuki, Penelitian Hukum, Prenada Media Group, Jakarta, 2005.

\section{PERATURAN-PERATURAN \\ PERUNDANG-UNDANGAN :}

Undang-Undang Dasar 1945

Undang-Undang Nomor 12 tahun 2011 tentang Pembentukan Peraturan Perundang -undangan

Peraturan Pemerintah Nomor 72 tahun 2005 tentang Desa

Peraturan Pemerintah Nomor 45 tahun 2007 tentang Persyaratan dan Tata Cara Pengangkatan Sekretaris Desa menjadi Pegawai Negeri Sipil

Peraturan Pemerintah Nomor 65 Tahun 2008 tentang Perubahan Kedua Atas Peraturan Pemerintah Nomor 32 Tahun 1979 tentang Pemberhentian Pegawai Negeri Sipil

Peraturan Daerah Kabupaten Lamongan tentang Pemerintahan Desa

Peraturan Bupati Lamongan tentang Penyelenggaraan Pemerintahan Desa 